\title{
A STUDY ON FOLLOWUP OF LOW BIRTH WEIGHT BABIES ON EXCLUSIVE BREAST FEEDING UPTO FOUR MONTHS OF AGE
}

\author{
Srinivasa Sharanappa1, Reshmavathi Venkatram² \\ 1 Professor and HOD, Department of Paediatrics, Kempegowda Institute of Medical Sciences and Research Hospital. \\ 2Junior Resident, Department of Paediatrics, Kempegowda Institute of Medical Sciences and Research Hospital.
}

\section{ABSTRACT}

\section{BACKGROUND}

Birth weight of a child is an important indicator of its vulnerability for childhood illness and chances of survival. A significant number of infant deaths can be averted by prevention of factors associated with LBW and adequate management of LBW babies. The incidence of low birth weight baby continues to be high in developing countries in contrast to developed countries.

\section{METHODOLOGY}

It was a prospective study conducted between October 2014 and September 2015. All babies delivered with a birth weight less than 2500 grams were included in the study. Detailed records were made regarding maternal history and new-born examination. Advantage of exclusive breast feeding explained to parents and advised to attend the Well Baby Clinic on Wednesdays at monthly intervals for first four months. During each visit growth parameters were measured, developmental milestones assessed. General physical examination and neurological examination done. Data analysed by Chi-square test and ANOVA test.

\section{RESULTS}

$21.4 \%$ of LBW babies were $>2000$ grams, $41.4 \%$ between $1500-2000$ grams and the remaining $<1500$ grams were $37.2 \%$. There was a significant association between head circumference, length and their gestational age. Among complication associated with neonates $74.4 \%$ cases were uncomplicated, $14.3 \%$ cases had hyperbilirubinaemia, $8.5 \%$ had respiratory problems and $2.8 \%$ had sepsis. From 0-4 months 70\% of LBW babies gained double the weight, $73 \%$ of LBW babies had an average of $7 \mathrm{cms}$ increase in head circumference, $81 \%$ of LBW babies had an average of $7 \mathrm{cms}$ increase in chest circumference and $57 \%$ showed increase of $10 \mathrm{cms}$ in length. Of the babies that had not attained social smile by three months, $66.7 \%$ of babies less than $1500 \mathrm{gms}$ and $22.2 \%$ were above 2000gms which are IUGR babies that had not attained social smile either. Among the babies that had not attained complete neck control by 4 months, $76.9 \%$ of babies less than 1500 gms.

\section{CONCLUSION}

Breast feed alone is sufficient for adequate growth in low birth weight babies. Antenatal and postnatal education for all mothers regarding breast feeding irrespective of gestational age and birth weight of baby is very important.

\section{KEYWORDS}

LBW, Head circumference, IUGR.

HOW TO CITE THIS ARTICLE: Sharanappa S, Venkatram R. A study on followup of low birth weight babies on exclusive breast feeding upto four months of age. J. Evolution Med. Dent. Sci. 2016;5(21):1128-1132, DOI: 10.14260/jemds/2016/262

\section{INTRODUCTION}

Birth weight is an important determinant of an infant's survival and future development. ${ }^{1}$ Babies with a birth weight of less than 2500gms irrespective of the period of gestation are called low birth weight babies. These include preterm and small for date term babies. ${ }^{2}$ The incidence of low birth weight baby continues to be high in developing countries like India at about $30 \%$ in contrast to $5-7 \%$ in developed countries. Out of 8 million LBW babies born in India every year, nearly 5.3 million babies are SGA. ${ }^{3}$ This study on LBW babies was undertaken to find out the incidence of low birth weight in Kempegowda Institute of Medical Sciences and also to followup the growth of these babies who were exclusively breast fed for a period of four months. The followup was

Financial or Other, Competing Interest: None.

Submission 06-01-2016, Peer Review 24-02-2016,

Acceptance 29-02-2016, Published 14-03-2016.

Corresponding Author:

Dr. Reshmavathi Venkatram,

37, $1^{\text {st }}$ Main, RMV, $2^{\text {nd }}$ Stage,

AmarJyothi Layout, Sanjaynagar,

Bangalore-560094.

E-mail:dr.reshma.venkatram@gmail.com

DOI: $10.14260 /$ jemds $/ 2016 / 262$ restricted to the first four months for logistic reasons, as many mothers shift to the husband's house after the $4^{\text {th }}$ month.

The present rate of infant mortality is $74 / 1000$, of which nearly two-third of deaths are due to neonatal mortality. Despite the advances in the neonatal care, our neonatal morbidity and mortality continues to be high. ${ }^{3}$ Hence, it is important to recognize IUGR babies because of high incidence of neonatal morbidity and its long-term sequences.

The factors responsible for LBW in our country is poor socioeconomic status contributing to maternal anaemia, inadequate prenatal care, improper pregnancy spacing, drug addiction, maternal infection, placental abnormalities and chronic illness. ${ }^{4}$

Neonatal morbidity and mortality bears inverse relationship with birth weight and gestation age. The LBW infants are five times more likely to die in the perinatal period and three times more likely to die among infancy. Hence, this study was undertaken.

\section{AIMS AND OBJECTIVES}

1. To estimate the incidence of low birth weight babies in Kempegowda Institute of Medical Sciences, Bangalore. 
2. To assess the growth and development of low birth weight babies for the first four months who are on exclusive breast feeding and who attended well baby clinic in Kempegowda Institute of Medical Sciences, Bangalore from October 2014 to September 2015.

\section{METHODOLOGY}

\section{Inclusion Criteria}

1. Birth weight less than 2500 grams.

2. Babies who were only breast fed till 4 months.

\section{Exclusion Criteria}

1. Congenital malformations like cleft lip, cleft palate.

2. With any congenital diseases.

3. Where breast feeding was contraindicated.

Study Period: October 2014 to September 2015.

All the babies delivered with a birth weight less than 2500 grams were included in the study and following details were recorded.

\section{Maternal History}

1. Chronic illness in mother.

2. Any illness during that pregnancy.

3. Previous obstetric history.

4. Delivery and its complications.

5. Socioeconomic status.

\section{For The Baby}

1. Birth weight, length, head and chest circumference.

2. Gestational age using New Ballard score.

3. Perinatal complications if any.

4. Any congenital complications.

The advantage of exclusive breast feeding was explained to the parents and they were advised not to give any other feeds and also explained about the importance of regular followup and neurological testing. They were asked to attend the well-baby clinic on Wednesdays at monthly intervals for first four months.

During each visit growth parameters were measured, developmental milestones were assessed and advice was given regarding feeding and immunization. A general physical examination and a neurological examination were done for all these babies in the study group. Vision and hearing was tested clinically.

Growth parameters (Length, weight, head and chest circumference) were taken at the time of examination. The neurological evaluation by Trivandrum Developmental Screening Chart was done, corrected age was used while evaluating preterm babies.

Cases that did not come for followup were telephonically informed to find out the reason for noncompliance and requested to come for followup clinic. Cases that showed developmental delay were again evaluated at 5 months and 6 months. Cases that still had developmental delay at 6 months were followed up with developmental neurologist.

\section{STATISTICAL METHOD}

1. Chi-square test is used to find out the association between two qualitative variables.

2. One way ANOVA test with repeated measures is used to compare the mean changes in growth parameters by month wise.

\section{RESULTS}

There were a total of 419 babies born during the study period. Out of these 124 had birth weight less than 2500, giving an incidence of $29.5 \%$, but only 70 cases were included in the study. Among these 22 were term and Small for Gestational Age (SGA)/IUGR, 8 were preterm and small for gestational age and 40 were preterm and Appropriate for Gestational Age (AGA).

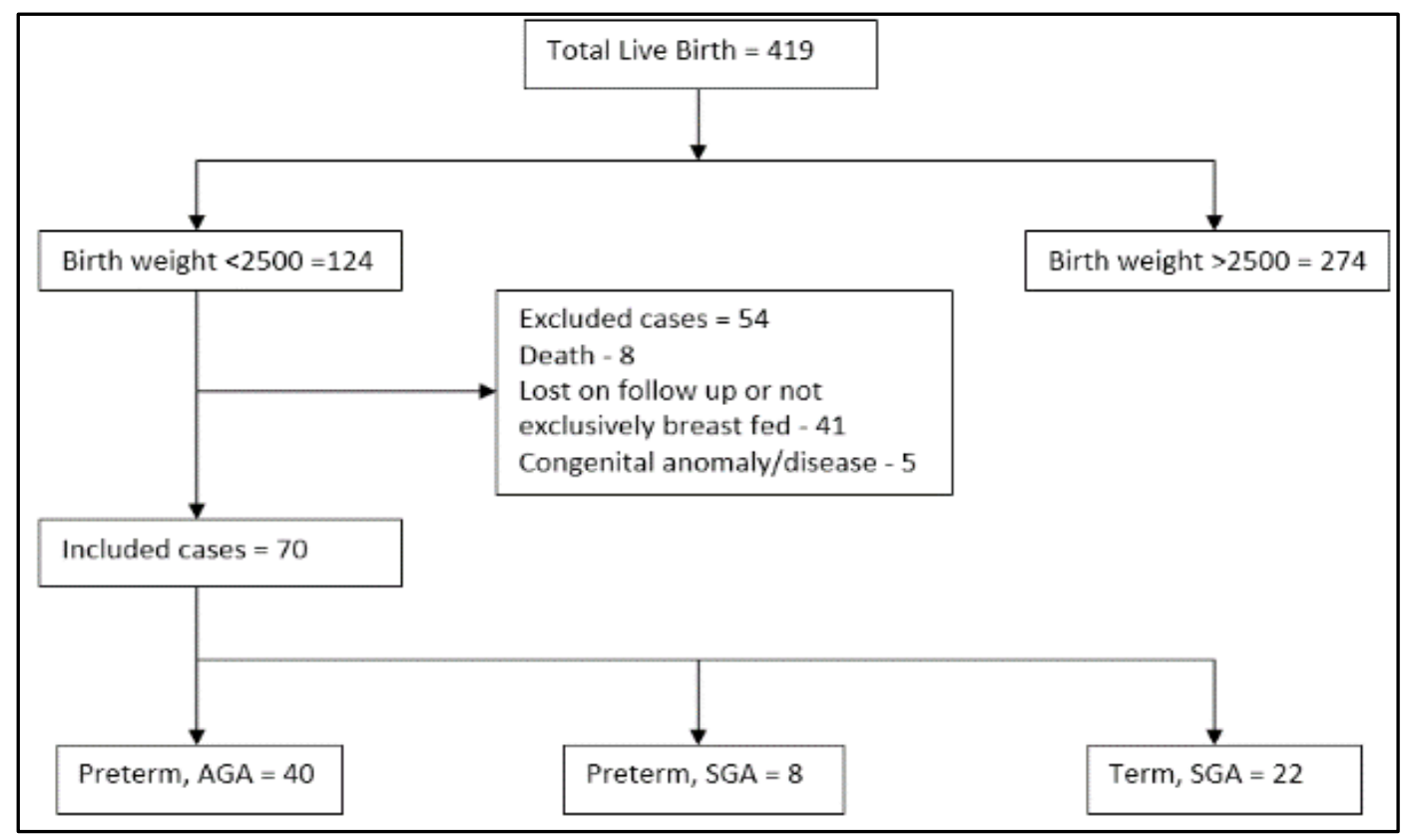

Fig. 1: Incidence of Low Birth Weight of the 70 cases studied 54.3\% (38) babies were female and $45.7 \%$ (32) babies were female 


\begin{tabular}{|c|c|c|c|c|}
\hline \multirow{2}{*}{} & \multicolumn{3}{|c|}{ GESTATIONAL AGE (Weeks) } & \multirow{2}{*}{ TOTAL } \\
\cline { 2 - 4 } & $28-32$ & $33-37$ & $>37$ & \\
\hline$<1500$ & 7 & 18 & 1 & 26 \\
\hline $1500-2000$ & 3 & 14 & 12 & 29 \\
\hline$>2001$ & 0 & 6 & 9 & 15 \\
\hline TOTAL & 10 & 38 & $\mathbf{2 2}$ & $\mathbf{7 0}$ \\
\hline \multicolumn{5}{|c|}{ HEAD CIRCUMFERENCE (cm) } \\
\hline$<28.5$ & 9 & 8 & 2 & 19 \\
\hline $28.5-31.5$ & 1 & 23 & 7 & 31 \\
\hline$>31.5$ & 0 & 7 & 14 & 20 \\
\hline TOTAL & 10 & 38 & $\mathbf{2 2}$ & $\mathbf{7 0}$ \\
\hline \multicolumn{5}{|c|}{ CHEST CIRCUMFERENCE (cm) } \\
\hline$<26$ & 17 & 4 & 0 & 21 \\
\hline $26-29$ & 2 & 22 & 8 & 32 \\
\hline$>29$ & 0 & 2 & 15 & 17 \\
\hline TOTAL & 19 & $\mathbf{2 8}$ & $\mathbf{2 3}$ & $\mathbf{7 0}$ \\
\hline \multicolumn{5}{|c|}{ LENGTH (cm) } \\
\hline$<40$ & 7 & 13 & 1 & 21 \\
\hline $40.1-45$ & 3 & 18 & 13 & 34 \\
\hline$>45$ & 0 & 7 & 8 & 15 \\
\hline TOTAL & 10 & $\mathbf{3 8}$ & $\mathbf{2 2}$ & $\mathbf{7 0}$ \\
\hline Table 1: Distribution of Weight, Head Circumference & and Length of LBW Babies at Birth \\
\hline & by their Gestational Age \\
\hline
\end{tabular}

\begin{tabular}{|c|c|c|c|}
\hline $\begin{array}{c}\text { Sl. } \\
\text { No. }\end{array}$ & COMPLICATIONS & $\begin{array}{c}\text { NO. OF } \\
\text { CASES }\end{array}$ & PERCENTAGE \\
\hline 1 & Sepsis & 2 & 2.8 \\
\hline 2 & $\begin{array}{c}\text { Respiratory } \\
\text { problems }\end{array}$ & 6 & 8.5 \\
\hline 3 & Hyperbilirubinaemia & 10 & 14.3 \\
\hline 4 & Uncomplicated & 52 & 74.4 \\
\hline 5 & \multicolumn{4}{|c|}{ TOTAL } & $\mathbf{7 0}$ & $\mathbf{1 0 0}$ \\
\hline \multicolumn{4}{|c|}{ Table 3: Neonatal Complications } \\
\hline
\end{tabular}

\begin{tabular}{|c|c|c|}
\hline & $\begin{array}{l}\text { NO. OF } \\
\text { CASES }\end{array}$ & PERCENTAGE \\
\hline \multicolumn{3}{|c|}{ BIRTH WEIGHT } \\
\hline $\begin{array}{l}\text { More than double the } \\
\text { birth weight }\end{array}$ & 49 & 70 \\
\hline $\begin{array}{l}\text { Less than double the birth } \\
\text { weight }\end{array}$ & 21 & 30 \\
\hline TOTAL & 70 & 100 \\
\hline \multicolumn{3}{|c|}{ HEAD CIRCUMFERENCE } \\
\hline More than $7 \mathrm{cms}$ & 51 & 72.9 \\
\hline Less than $7 \mathrm{cms}$ & 19 & 27.1 \\
\hline TOTAL & 70 & 100 \\
\hline \multicolumn{3}{|c|}{ CHEST CIRCUMFERENCE } \\
\hline More than $7 \mathrm{cms}$ & 57 & 81.4 \\
\hline \multirow[t]{2}{*}{ Less than $7 \mathrm{cms}$} & 13 & 18.6 \\
\hline & 70 & 100 \\
\hline \multicolumn{3}{|c|}{ LENGTH } \\
\hline More than $10 \mathrm{cms}$ & 40 & 57 \\
\hline \multirow[t]{2}{*}{ Less than $10 \mathrm{cms}$} & 30 & 43 \\
\hline & 70 & 10 \\
\hline $\begin{array}{c}\text { Table 4: Improvement in } \\
\text { Chest Circumference, Len }\end{array}$ & $g h t, H e$ & $\begin{array}{l}\text { umference, } \\
\text { urth month }\end{array}$ \\
\hline
\end{tabular}

\begin{tabular}{|c|c|c|c|}
\hline $\begin{array}{c}\text { Sl. } \\
\text { No. }\end{array}$ & COMPLICATIONS & $\begin{array}{c}\text { NO. OF } \\
\text { CASES }\end{array}$ & PERCENTAGE \\
\hline 1 & $\begin{array}{c}\text { Bad obstetric } \\
\text { history }\end{array}$ & 2 & 2.9 \\
\hline 2 & Twins & 8 & 11.4 \\
\hline 3 & Eclampsia/PIH & 7 & 10.0 \\
\hline 4 & Anaemia & 11 & 15 \\
\hline 5 & Diabetes & 1 & 1.4 \\
\hline 6 & UTI & 1 & 1.4 \\
\hline 7 & Malnutrition & 40 & 57 \\
\hline 8 & Total & $\mathbf{7 0}$ & $\mathbf{1 0 0}$ \\
\hline \multicolumn{4}{|c|}{ Table 2: Complications of Pregnancy } \\
\hline
\end{tabular}

\begin{tabular}{|c|c|c|c|c|c|c|c|}
\hline \multirow{3}{*}{$\begin{array}{l}\text { BIRTH WEIGHT } \\
\text { (gms) }\end{array}$} & \multicolumn{6}{|c|}{ SOCIAL SMILE } & \multirow{3}{*}{ TOTAL } \\
\hline & \multicolumn{3}{|c|}{ 2-3 Months } & \multicolumn{3}{|c|}{$>3$ Months } & \\
\hline & Preterm & Term & Total & Preterm & Term & Total & \\
\hline$<1500$ & 20 & 0 & $20(32.8 \%)$ & 5 & 1 & $6(66.7 \%)$ & 26 \\
\hline $1500-2000$ & 16 & 12 & $28(45.9 \%)$ & 1 & 0 & $1(11.1 \%)$ & 29 \\
\hline$>2000$ & 4 & 9 & $13(21.3 \%)$ & 2 & 0 & $2(22.2 \%)$ & 15 \\
\hline
\end{tabular}

Chi-square $=4.718, \mathrm{p}=0.095$

There were 9 babies that had not attained social smile by the age of 3 months. Of these 9 babies, one was term and rest were preterm. These babies were followed up again at age of 4 months, by then only 5 babies had not attained social smile. By 5 months of age 3 babies had not achieved social smile, two were preterm who had reached corrected age of 3 months and one term baby.

\begin{tabular}{|c|c|c|c|c|c|c|c|c|c|c|}
\hline \multirow{3}{*}{ BIRTH WEIGHT (gms) } & \multicolumn{6}{|c|}{ HEAD HOLDING } & \multirow{2}{*}{\multicolumn{3}{|c|}{$\begin{array}{c}\text { NO HEAD HOLDING } \\
>4 \text { months }\end{array}$}} & \multirow{3}{*}{ TOTAL } \\
\hline & \multicolumn{3}{|c|}{ 3-3.5 months } & \multicolumn{3}{|c|}{ 3.5-4 months } & & & & \\
\hline & PT & $\mathrm{T}$ & Total (\%) & PT & $\mathrm{T}$ & Total & $\mathrm{PT}$ & $\mathrm{T}$ & Total (\%) & \\
\hline$<1500$ & 4 & 0 & $4(21.0)$ & 12 & 0 & $12(31.5)$ & 9 & 1 & $10(76.9)$ & 26 \\
\hline $1500-2000$ & 3 & 7 & $10(52.6)$ & 13 & 5 & $18(47.3)$ & 1 & 0 & $1(7.7)$ & 29 \\
\hline$>2000$ & 0 & 5 & $5(26.4)$ & 4 & 4 & $8(21.0)$ & 2 & 0 & $2(15.3)$ & 15 \\
\hline
\end{tabular}

Chi-square $=6.812, \mathrm{p}=0.001$, PT - Preterm, T- Term.

There were 13 babies that had not attained complete neck control by 4 months. Amongst these 12 were preterm and
1 was term baby. These babies were followed up again at 5 months, 5 of them had attained neck control. They were again 
followed at 6 months, only 4 babies ( 3 preterm and 1 term) had not attained neck control. These babies that had not attained neck holding or social smile were closely monitored and regularly assessed by developmental neurologist.

\section{ANOVA Test with the Repeated Measurements showed the following:}

1. The mean birth weight of the babies were $1.70 \mathrm{kgs}$ with the standard deviation of $0.39 \mathrm{kgs}$ at birth. It increases to $2.07 \mathrm{kgs}$ at $1^{\text {st }}$ month with the SD of $0.43 \mathrm{kgs}$ and further it is increased to $2.65 \mathrm{kgs}, 3.23 \mathrm{kgs}$ and $3.77 \mathrm{kgs}$ respectively on $2^{\text {nd }}, 3^{\text {rd }}$ and $4^{\text {th }}$ month.

2. The head circumference of the babies were $30.02 \mathrm{cms}$ with the SD of $2.24 \mathrm{cms}$ at birth. It is increased to $31.7 \mathrm{cms}$ at 1 st month with the SD of $4.11 \mathrm{cms}$ and further it is increased to $34.20 \mathrm{cms}, 36.03 \mathrm{cms}$ and $37.22 \mathrm{cms}$ respectively on $2^{\text {nd }}, 3^{\text {rd }}$ and $4^{\text {th }}$ month.

3. The mean chest circumference of the babies were $26.97 \mathrm{cms}$ with the SD of $3.92 \mathrm{cms}$ at birth. It is increased to $29.23 \mathrm{cms}$ at $1^{\text {st }}$ month with the SD of $2.30 \mathrm{cms}$ and further it is increased to $31.14 \mathrm{cms}, 33.33 \mathrm{cms}$ and $39.35 \mathrm{cms}$ respectively on $2^{\text {nd }}, 3^{\text {rd }}$ and $4^{\text {th }}$ month.

4. The mean length of the babies were $42.26 \mathrm{cms}$ with the SD of $3.10 \mathrm{cms}$ at birth. It is increased to $44.90 \mathrm{cms}$ at $1^{\text {st }}$ month with the SD of $3.10 \mathrm{cms}$ and further it is increased to $47.65 \mathrm{cms}, 50.10$ and $51.71 \mathrm{cms}$ respectively on $2^{\text {nd }}, 3^{\text {rd }}$ and $4^{\text {th }}$ month.

\section{DISCUSSION}

Birth weight is generally used as a yardstick of maturity. It is an important determinant of child survival and development. ${ }^{5}$ It is also a subject of clinical and epidemiological investigations and a target for public health intervention. ${ }^{6}$ The incidence of LBW babies in this study was found to be $29.5 \%$.

Vijay Bhargava, et al. noted a female preponderance in the sex distribution. ${ }^{7}$ The present study showed similar distribution of girls and boys among LBW babies. There was slightly higher preponderance of female (54.3\%) over males (45.7\%); $21.4 \%$ of LBW babies were more than 2000 grams, $41.4 \%$ between 1500 to 2000 grams and the remaining $37.2 \%$ were less than 1500 grams. Thus, there is direct correlation between the birth weight and their gestational age (Table 1). Vijay Bhargava et al. also showed the same result.7

There was a significant association between the head circumference, length and their gestational age at birth (Table 1).

The complications of pregnancy which resulted in LBW babies were malnutrition (57\%), anaemia (15\%), 11\% were twins and $10 \%$ were pregnancy-induced hypertension (Table 2). C. M. Drillen et al. showed the similar incidence of complicated pregnancies.8,9,10 Among the complication associated with neonates $74.4 \%$ cases were uncomplicated, $14.3 \%$ cases had hyperbilirubinemia, $8.5 \%$ had respiratory problems and $2.8 \%$ had sepsis. (Table 3 ) $70 \%$ of LBW babies gained double the weight from birth to fourth month of age, while $30 \%$ of LBW babies had not doubled the weight (Table 4). Kitchei et al. also showed similar results. ${ }^{10} 73 \%$ of LBW babies had an average of $7 \mathrm{cms}$ increase in head circumference, while $27 \%$ had not reached the average of $7 \mathrm{cms}$. Fewtrell et al. had shown similar catch up growth in head circumference. ${ }^{11}$ $81 \%$ of LBW babies had an average of $7 \mathrm{cms}$ increase in chest circumference, while $19 \%$ of LBW babies not reached the average of $7 \mathrm{cms}$. N.H. Kitchei et al. and O.P. Ghai, Chinn S et al. observed that low birth weight babies gained length at a slower rate. ${ }^{12,13}$ In the present study, $57 \%$ of LBW babies showed an increase of $10 \mathrm{cms}$ over the four months and $43 \%$ of babies showed less than $10 \mathrm{cms}$ increase in length (Table 4).

The large majority of developmental delays could be identified by using cut off points for two simple developmental milestones, namely social smile completed by two months and head holding completed by three months. Trivandrum Development Screening Chart (TDSC) is used for development assessment. ${ }^{14}$

There were 9 babies that had not attained social smile by the age of three months, $66.7 \%$ of babies less than $1500 \mathrm{gms}$ and $22.2 \%$ were above $2000 \mathrm{gms}$ (Table 5). These babies were followed till 5 months and finally 3 babies had not achieved social smile, two were preterm who had reached corrected age of 3 months and one term baby. There were 13 babies that had not attained complete neck control by 4 months $76.9 \%$ of babies less than 1500gms (Table 6). These babies were followed till 6 months and only 4 babies (3 preterm and 1 term) had not attained neck control. This implied that though babies could achieve appropriate milestone based on their corrected postnatal age, it is essential to monitor their development. TDSC serves as a helpful tool in identifying the babies that require frequent developmental monitoring.

\section{CONCLUSION}

Breast feed alone is sufficient for adequate growth of low birth weight babies. Antenatal and postnatal education for all mothers regarding breast feeding, irrespective of gestational age and birth weight of baby is very important. Regular developmental monitoring with simple developmental scales like TDSC helps identification of developmental delay in these low birth weight babies.

\section{REFERENCES}

1. Wilcox AJ. On the importance-and the unimportance-of birthweight. International Journal of Epidemiology 2001;30:1233-1241.

2. Ronald S Illingworth. The development of the infant and young child-low birth weight babies. Harcourt publications. 1999;9th edition:27-28.

3. Meharban Singh. Care of the newborn, CBS publications. 2015;8th edition:299-300.

4. Ghai OP. Early postnatal growth pattern of very low birth weight babies. Indian Paediatrics 1978;11(11).

5. WHO. Division of family health. The incidence of low birth weight, a critical review of available information. World Health Stat Q 1980;33:97-224.

6. UNICEF/WHO Low Birth weight, Country, Regional and Global Estimates. 2006.

7. Vijaya Bhargava, Sreedip G, Krishnakanth B. Survival growth and development in babies weighing 2000 grams or less. Indian paediatrics 1970;7(3):139-45.

8. Kumari S, Shendurnikar N, Jain S, et al. Outcome of low birth weight babies with special reference to some maternal factors. Indian paediatrics 1989;26:241-246.

9. Cecil M Drillien. A longitudinal study of the growth and development of prematurity and maturity born children. Archives of diseases in children 1961;36:72-74. 
10. Maureen Hack, Harried F, Avroy AF. Outcome of extremely low birth weight infants. Paediatrics 1996;98(5):24-25.

11. Fewtrell MS, Morley R, Abbott RA, et al. Catch up growth in small for gestational age term infants: a randomized trial. Am J Clin Nutr 2001;74(4):516-23.

12. Kitchei NH. A longitudinal study of very low birth weight infants. Development medicine and child neurology 1980;22:163-171.
13. Chinn S, Rona RJ, Price CE. Need for new reference curves for height. Archives of Diseases in childhood 1989;64:1545-1553.

14. Nair MKC, George B, Philip E, et al. Trivandrum developmental screening chart. Indian Paediatrics 1991;28(8):869-872. 